\section{(6) \\ OPEN ACCESS}

\title{
Recurrent meningitis caused by idiopathic cerebrospinal fluid rhinorrhoea from the sphenoid sinus
}

\author{
Motoki Hirabayashi, ${ }^{1}$ Kazuhiro Omura, ${ }^{2,3}$ Nobuyoshi Otori, ${ }^{2}$ Yasuhiro Tanaka ${ }^{3}$
}

\begin{abstract}
- Additional material is published online only. To view please visit the journal online (http://dx.doi.org/10.1136/ bcr-2017-222296).
\end{abstract}

'Department of

Otorhinolaryngology, Asahi General Hospital, Chiba, Japan ${ }^{2}$ Department of

Otorhinolaryngology, The Jikei University School of Medicine, Tokyo, Japan

${ }^{3}$ Department of

Otorhinolaryngology, Dokkyo Medical University Saitama Medical Center, Saitama, Japan

Correspondence to Dr Kazuhiro Omura, kazuhiro.omura@jikei.ac.jp

Accepted 12 December 2017

Check for updates

To cite: Hirabayashi $\mathrm{M}$, Omura K, Otori N, et al. BMJ Case Rep Published Online First: [please include Day Month Year]. doi:10.1136/ bcr-2017-222296

\section{DESCRIPTION}

A 41-year-old woman with 7 days of fever and headache had loss of consciousness 1 day prior to presentation. Despite the absence of trauma or other significant medical history, she had two episodes of meningitis in the previous 6 months. Physical examination showed no nuchal rigidity or abnormal findings on nasal endoscopy. Lumbar puncture showed a cerebrospinal fluid

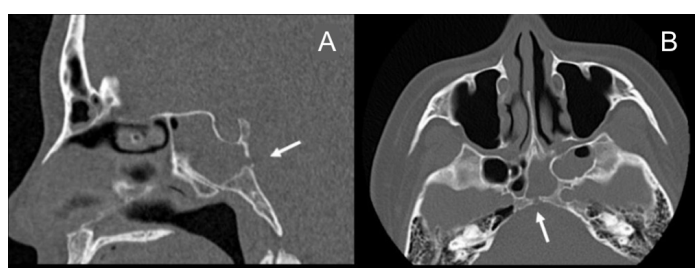

Figure 1 A bony defect of the posterior wall of the sphenoid sinus (arrows): (A) CT with sagittal view and (B) CT with axial view.

\section{Learning points}

- Idiopathic cerebrospinal fluid rhinorrhoea (ICFR) is seen most often among middle-aged obese women. These patients tend to experience rhinorrhoea as the primary symptom, but meningitis is also often an initial symptom.

- The typical cause of ICFR in the sphenoid sinus appears to involve a congenital bone union disorder of the posterior and lateral walls of the sinus, sometimes with meningoencephalocele. $\mathrm{CT}$ in this case showed a bony defect on the posterior wall of the sphenoid sinus, $6 \mathrm{~mm}$ below the sella floor. The exact site of the submucosal defect must be identified to achieve close approximation for reconstruction with abdominal fat, and sometimes a nasoseptal mucosal flap.

- In cases of recurrent meningitis with cerebrospinal fluid rhinorrhoea, transnasal reconstruction with endoscopic sinus surgery is the first choice. Early consultation with otolaryngology and surgical reconstruction lead to a good outcome. cell count of $750 / \mu 1$. CT showed a bony defect of the posterior wall of the sphenoid sinus, which was filled with a soft tissue density. MRI showed fluid intensity in the same area (figure 1A, B). The diagnosis was recurrent meningitis due to possible idiopathic cerebrospinal fluid rhinorrhoea. Although a cisternogram is normally recommended, emergency drainage of the sphenoid sinus with antibiotic treatment was prioritised because of her deteriorating condition. With various possible diagnoses, an experienced surgeon operated on the patient.

Endoscopic sinus surgery was performed emergently under general anaesthesia for drainage and reconstruction of the bony defect, $6 \mathrm{~mm}$ below the sella floor (online supplementary video 1) in the sphenoid sinus.

The exact site of the submucosal defect was identified and reconstructed with nasoseptal mucosal flap with fat (online supplementary video 2) watery rhinorrhoea stopped soon after the operation. She was treated with cefotaxime $6 \mathrm{~g} /$ day for 2 weeks, made good progress and was discharged. At 38 months postoperatively, there is no evidence of recurrence based on both endoscopic evaluation and radiographic analysis.

Contributors $\mathrm{MH}$ and $\mathrm{KO}$ experienced this case. $\mathrm{MH}$ drafted the manuscript, and $\mathrm{KO}$ designed the figures and videos and did critical revision of the article. NO and YT gave final approval of the version to be published.

Funding The authors have not declared a specific grant for this research from any funding agency in the public, commercial or not-for-profit sectors

Competing interests None declared.

Patient consent Obtained.

Provenance and peer review Not commissioned; externally peer reviewed.

Open access This is an Open access article distributed in accordance with the Creative Commons Attribution Non Commercial (CC BY-NC 4.0) license, which permits others to distribute, remix, adapt, build upon this work non-commercially, and license their derivative works on different terms, provided the original work is properly cited and the use is non-commercial. See: http://creativecommons.org/licenses/by-nc/4.0/

(c) BMJ Publishing Group Ltd (unless otherwise stated in the text of the article) 2018. All rights reserved. No commercial use is permitted unless otherwise expressly granted. 
Copyright 2018 BMJ Publishing Group. All rights reserved. For permission to reuse any of this content visit http://group.bmj.com/group/rights-licensing/permissions.

BMJ Case Report Fellows may re-use this article for personal use and teaching without any further permission.

Become a Fellow of BMJ Case Reports today and you can:

- Submit as many cases as you like

- Enjoy fast sympathetic peer review and rapid publication of accepted articles

Access all the published articles

- Re-use any of the published material for personal use and teaching without further permission

For information on Institutional Fellowships contact consortiasales@bmjgroup.com

Visit casereports.bmj.com for more articles like this and to become a Fellow 